\title{
Marine silicate weathering (MSiW) products in the input sequence to the Sumatra subduction zone: carbon cycling implications
}

\author{
MARTA E TORRES ${ }^{1}$, KITTY MILLIKEN ${ }^{2}$, ANDRE \\ HUEPERS $^{3}$ AND JI-HOON KIM ${ }^{4}$ \\ ${ }^{1}$ Oregon State University \\ ${ }^{2}$ University of Texas at Austin \\ ${ }^{3}$ University of Bremen \\ ${ }^{4}$ KIGAM \\ Presenting Author: mtorres@coas.oregonstate.edu
}

Widespread weathering of reactive silicates in anoxic marine sediment impact geochemical budgets of cations and seawater alkalinity, with significant consequences for the global carbon cycle and Earth's climate through time. This reaction consumes $\mathrm{CO}_{2}$ and increases alkalinity, dissolved silica and cations. Here we present data collected outboard the Sumatra subduction zone to document conditions that result in the precipitation of authigenic carbonates -which sequester carbon- and contrast these with those leading to formation of authigenic clays -which release $\mathrm{CO}_{2}-$.

The ${ }^{87} \mathrm{Sr} /{ }^{86} \mathrm{Sr}$ ratio in pore fluids from Sites U1480 and U1481, show a marked increase to 0.71376 and 0.71296 , respectively, indicative of alteration of continent-derived reactive silicates shed from the Himalayas. Peaks in the pore fluid isotope data coincide with zones of methane presence, consistent with marine silicate weathering $(\mathrm{MSiW})$ reactions driven by $\mathrm{CO}_{2}$ generation during methanogenesis.

MSiW during early deposition of Bengal-Nicobar fan offshore Sumatra ( $\sim 9 \mathrm{Ma})$ coincided with large Ca flux from underlying oceanic crust, leading to significant formation of authigenic carbonate enriched in ${ }^{87} \mathrm{Sr}$ and in $\mathrm{Fe}, \mathrm{Mn}$ (siderite and mangoan calcite). Petrologic data shows dramatic carbonate replacement of silicates in the deeper older portions of the Nicobar Fan, supporting the in-situ nature of the dissolution/replacement.

During later stages of Bengal-Nicobar fan deposition ( $~ 5 \mathrm{Ma})$, MSiW result in authigenic clay mineral formation, possibly driven by silica supplied from biogenic opal dissolution in most recent sediments, with a lesser role in authigenic carbonate formation. Scanning electron microscopy (SEM) in the upper 200 mbsf at Site U1480 reveal partially altered feldspar showing dissolution pits and authigenic clay minerals nucleating upon feldspar surfaces.

These results illustrate how MSiW leads to distinct products, likely in response to a supply of silica in the modern setting and calcium enrichment via diffusion from oceanic basement in the older sequences, with contrasting effects on carbon inventories. 